\title{
A felsőoktatás oktatóinak szakmai fejlődése: az oktatói identitás alakulása és a tanulás módjai
}

\author{
Kálmán Orsolya*
}

Az oktatók mint tanárok szakmai fejlődése és tanulása kevéssé feltárt a hazai felsőoktatási kontextusban, pedig a tanulás-tanítás minőségének javitása egyre nagyobb figyelmet kap a nemzetközi térben. Jelen kvalitativ kutatás célja, hogy az oktatók oktatói önértelmezéseit és ezek változását, az oktatói identitáskonstrukciókhoz kötődő tanulási folyamatokat azonositsa. Tizenkét, az oktatásra nyitott oktatóval készítettünk élettörténeti és kvalitativ tematikus interjút. Az oktatói mintaválasztásba négy területrōl (pedagógusképzés, állam- és jogtudományi, gazdaságtudományi, orvostudományi) kerültek be kezdó, tapasztalt és az oktatás területén vezetői gyakorlattal rendelkező, tapasztalt oktatók. Az élettörténeti interjúk kiegészültek az időszalag és a kritikus esemény technikájával. Mindezek alapján a narratív elemzés az oktatói élettörténetekben megjelenő identitáskonstrukciókat és ezekhez kötódó jellegzetes időszako kat azonosította, majd a mintázatokban megjelenő különbségeket vizsgáltuk meg a három oktatói csoport közt és azon belül is. Az eredmények azt mutatják, hogy a három oktatói csoport önértelmezései eltérő mintázatokat mutat nak: a kezdő oktatók önértelmezésében jelentős lépést jelent a hallgatóközpontú tanításra figyelő oktató, a tapasztalt oktatóknál a tudatos, pedagógiai megközelítéssel rendelkező oktató képének megjelenése, míg a vezetói gyakorlattal is rendelkező oktatók a tanulásközpontú, magukat is tanulóként értelmező oktatói önértelmezést emelték ki. Az oktatásfejlesztéshez kötődő feladatok és szerepek minden oktatói csoport számára önértelmezést alakító tényezőkként jelentek meg és lényeges tanulási folyamatokat is ösztönöztek. Eredményeinkkel hozzá kívánunk járulni a tanulásközpontú pedagógia és az oktatói önértelmezések árnyalt értelmezéséhez, valamint a támogatási lehetőségek megalapozott tervezéséhez.

Kulcsszavak: oktatók, szakmai fejlődés és tanulás, narratív megközelítés

„...és akkor felmerül, hogy jé, igazából ez egy szakma is, hogy ezt lehetne esetleg tanulni is”

\section{Bevezetés}

A nemzetközi térben egyre több szó esik a felsőoktatásban a tanulás-tanítás funkcióinak felértékelődéséről, az oktatás minőségének javításáról (Hénard \& Rosevare, 2012), arról, hogy a kutatás és oktatás egyensúlyát újra meg kell teremteni, hogy az oktatók szakmai fejlódésével, pedagógiai képzésével foglalkozni kell, hogy az oktatás fejlesztésének ösztönzése elengedhetetlen, hogy a tanítás nem lehet oktatók, hallgatók egyéni ügye, hanem intézményi, kormányzati támogatás szükséges hozzá (EC, 2014). Mindehhez képest keveset tudunk arról, hogy a hazai felsőoktatásban az oktatók ténylegesen hogyan gondolkodnak arról, hogy mit jelent tanárnak/oktatónak' lenni, hogyan tanulható és hogyan tanulják ezt a szakmai szerepet, vagy a tanítást magát, egyáltalán

ELTE PPK Neveléstudományi Intézet, e-mail: kalman.orsolya@ppk.elte.hu

1. Fontos megjegyezni, hogy a magyar nyelvben az oktató két jelentéssel bír: egyrészt tág értelemben használjuk a felsőoktatás ban oktatói státuszban dolgozókra (academic), másrészt szűkebb értelemben egy speciális szerepkörre, a tanári munkához 
hogyan gondolkodnak az oktatói fejlődésükről, tanulásukról. A kevés hazai kutatási eredmény (Kálmán, 2016; Kovács \& Kereszty, 2016) is olyan kérdőíves vizsgálatokból származik, ami az oktatói gondolkodásmódot kevésbé komplexen tudja megragadni. A tanulmány ezeket a kérdéseket járja körül, mégpedig úgy, hogy magukat az oktatókat szólítja meg, az ő értelmezésüket kívánja feltárni. Mindez különösen lényeges, hiszen az oktatás minőségének javítása, a tanulás-tanítás valódi felértékelődése nem mehet végbe az oktatók nézőpontjának, el képzeléseinek érvényesülése nélkül. A kvalitatív kutatásban különböző szakterületekről érkezett tizenkét, az oktatást fontosnak tartó oktató szakmai élettörténetét, oktatói önértelmezését, szakmai tanulását elemeztük.

\section{Elméleti keretek az oktatók szakmai fejlődéséhez}

\section{A szakmai fejlődés értelmezése}

A szakmai fejlődés fogalma elsősorban a pedagógus professzió, professzionalizálódás és az oktatás eredményessége kapcsán jelent meg, s hozott mostanra számos kutatási eredményt (pl. Sachs, 2007; Cordingley, 2015; Rapos, 2016). A felsőoktatás nemzetközi és különösen hazai szakirodalmában viszont sokkal frissebb a problémakör, aminek megerősödése nyilván nem független azoktól a tendenciáktól, amelyek az oktatás minőségének javítását tǔzik ki célul. A szakmai fejlődés problémavilágának lényeges és sajátos eleme a felsőoktatásban: hogy az oktatók hagyományosan nemcsak oktatói szerepben dolgoznak, hanem kutatói, fejlesztői, tanácsadói stb. szerepekben is; valamint hogy az oktatók szakmai fejlődésére, tanulására jóval kevésbé épültek ki átgondolt, tervezett vagy akár formális képzések (pl. nem szükséges tanári végzettség, képzés az oktatói feladatok ellátásához). A szakmai fejlődés fogalmának értelmezését tehát két szinten lehet megragadni a felsőoktatásban dolgozó oktatók esetében. Egyrészt a szakmai fejődés kötődhet az oktatói szerephez (professional development), másrészt holisztikusan az oktatói státuszhoz kötődő fejlődéshez, amiben az oktatói, kutatói, további pl. szakértói, tanácsadó szerepek tanulása is megjelenik (academic development, faculty development). ${ }^{2}$ A szakmai fejlődés eredendően az egyéni oktatói fejlődésre vonatkozott, de jellemzően egyre inkább összekapcsolódik az oktatóközösségek és a szervezetek tanulásával is (Vö: Taylor \& Colet, 2010). A szakmai fejlődés másik speciális sajátossága, hogy hagyományosan az egész szakmatanulási folyamat egy nem tervezett szakmai szocializációként értelmeződik, s csak az utóbbi időben jelennek meg azok a hangok, amelyek az oktatási tevékenységekre való felkészülés és folyamatos támogatás tervezett, átgondolt támogatását is meghatározónak tartják. Éppen ezért a tanulmányban a szakmai fejlődés és tanulás fogalmát ${ }^{3}$ leginkább együtt használom, ezzel érzékeltetve, hogy 1) nem csak az egyéni oktatói fejlődést tartjuk meghatározónak, 2) hogy a szakmai fejlődés és tanulás bonyolult kapcsolatát érzékeljük - nem beszélhetünk egyértelmúen lineáris fejlődésről, a tudatosan tervezett fejlődés és ennek támogatása gyakran szinte teljesen hiányzik, s inkább az informális tanulás reflektálatlan formái kapcsolódnak a szakmai fejlődéshez.

kapcsolódó szerepre. A tanulmány alapvetően az oktató fogalmának szűkebb értelmére fókuszál, így ha tágabb értelemben használom, azt jelzem.

2. Leginkább az észak-amerikai gyakorlatban és kutatásban használják (Vö: Taylor \& Colet, 2010).

3. A pedagóguskutatások újabban szintén a „folyamatos szakmai fejlődés és tanulás” terminológiát kezdik el használni (Id. Cordingley, 2015). 
Mindezek alapján az oktatói szakmai fejlődés és tanulás értelmezésében a következő elemeket, jellemzőket tartjuk meghatározónak (pl. Day, 1999; Rapos, 2016; Taylor \& Colet, 2010; Horváth, Simon \& Kovács, 2016):

a) az elköteleződések, célok folytonos reflexiója, ami kapcsolódik a szakmai identitás folytonos újrakonstruálásához;

b) a szakmai fejlődés és tanulás folyamatossága a szakmai életút során;

c) a szakmai aktivitás, ágencia fontossága egyéni és kollektív szinten;

d) az intézményi kontextusba, szervezetbe ágyazottság;

e) a szakmai fejlődés eredményessége és a tanulók/hallgatók tanulásának összekapcsolása;

f) a szakmai fejlődés, tanulás elválaszthatatlansága a támogatási rendszerektől, formáktól.

Jelen tanulmány az oktatók szakmai fejlődésének értelmezésekor elsősorban az első két jellegzetesség feltárására fókuszál.

\section{Oktatói identitáskonstruálás a szakmai fejlődésben}

A felsőoktatásban a szakmai fejlődés kutatása leginkább a szakmai identitás alakulásához kötődik. A szakmai fejlődést általános értelemben a szakmai identitás fejlődéseként is értelmezhetjük (pl. Swennen, Jones \& Volman, 2010). Ebben a megközelítésben a szakmai identitás egyfajta önértelmezés, önmegértés, mely a korábbi tapasztalatok és jövőbeli tervek folyamatos reflexiója során alakul (Kelchtermans, 2009; Beijaard, Meijer \& Verloop, 2004). Alapvetően azt mutatja meg, hogy hogyan látja magát az oktató mint oktató. A szakmai identitáskonstruálás tehát egy folyamatos, a személy és a kontextus viszonyában alakuló értelmezési és újraértelme zési folyamat, ami végigkíséri az oktatói karrier egészét. A gyakorlatok és szerepek folytonos reflexiója, a fejlődési célokkal és kihívásokkal való azonosulás, az alternatív gyakorlatok megteremtése mind alakítói a szakmai önértelmezésnek és fejlődésnek (Korhonen \& Törmä, 2016 idézi Trautwein, 2018). A szakmai identitás újrakonstruálása egyaránt jelenti azt, hogy az identitás rugalmas, nyitott a változásra, s hogy egy folytonos tudatos reflektív munkára is szükség van.

Az oktatók szakmai identitásának jellemzője, hogy nemcsak időben változhat az újraértelmezések során, hanem, hogy eleve nem egy koherens identitásról, hanem számos alidentitásból álló „rendszerről” beszélhetünk. Az alidentitások kapcsolódhatnak a sokféle akadémiai szerephez (pl. oktatói, kutatói), de kötődhetnek új oktatási feladatokhoz is (pl. képzési program felelőse, oktatástechnológiai fejlesztő, az oktatókat támogató képző).

A változó felsőoktatási kontextus a szakmai identitás folytonos újragondolását, újraértelmezését követeli meg, az identitás- és alidentitáskonstrukciók változó, dinamikus, fluid jellegét erősíti fel (Akkerman \& Meijer, 2011). Ugyanakkor mindezzel együtt jár egy integrációs törekvés is, amelyben az egyén személyes tudását, nézeteit, attitűdjeit, értékeit integrálni akarja egymással és a szakmai követelményekkel, amelyek érkezhetnek az egyetemtől, gyakorlattól, széles körben elfogadott standardokból (Vö. Beijaard et al., 2004). Különösen fontos, hogy ezek az integráló törekvések számos feszültséget is felszínre hozhatnak: belső feszültségek keletkezhetnek az oktatók számára meghatározó személyes és szakmai azonosulások összeütközéseiből, de feszültségeket indukálhatnak az új szerepek, elvárások, intézményi innovációk is. Ebben a változásokra nyitott, ugyanakkor integrációra törekvő identitáskonstruálási folyamatban felértékelődik az ágencia szerepe. Eteläpelto és munkatársai (2013) szakirodalmi elemzésükben a szakmai ágenciát úgy definiálták, hogy amikor egyes szakemberek vagy szakmai közösségek befolyásolnak, választanak, állást foglalnak oly módon, hogy az munkájukra és szak- 
mai identitásukra hatással van. A szakmai ágencia tehát az adott struktúra keretei, valamint az egyéni és kollektív intenciók egymásra hatásában jön létre.

Tanulmányunk meghatározó kiindulópontja tehát az oktatói önértelmezések folyamatos újrakonstruálásának azonosítása az oktatói karrier egészében, különös figyelmet fordítva az újonnan megjelenő oktatói feladatok és az oktatói alidentitás differenciálódásának hatásaira. A tanulmányban az oktatói (tanári) identitáskonstruálást egy alidentitásként értelmezzük, aminek további, akár más szerepekhez kötődő alidentitásai is lehetnek (pl. fejlesztő). A szövegben ugyanakkor a bonyolultság elkerülése érdekében leggyakrabban az oktatói identitás kifejezést használjuk.

\section{Kutatási eredmények az oktatói identitáskonstruálásról, szakmai fejlődésről és tanulásról}

Az utóbbi időben egyre nagyobb érdeklődés övezi nemzetközi szinten az oktatók oktatói/tanári identitás alakulását, differenciált értelmezését, és a szakmai fejlődés jellegzetességeit, a támogató és hátráltató elemeket. Az ezzel kapcsolatos új eredményeket foglaljuk össze ebben a részben. 2017-ben van Lankveld és kollégái tematikus szakirodalmi szintézisükben már 59, főként kvalitatív jellegú kutatást dolgoztak fel a témában. Bár az oktatói identitásfejlődés nem problémamentes folyamat, szintézisükben találtak olyan tényezőket, amelyek elősegítik, erősítik a folyamatot, mint például a tanítás intézményi elismertsége, a kompetenciaérzet, az oktatói összetartozás érzése, az oktatói fejlődés lehetősége a karrierben, vagy a tanítás iránti elköteleződés.

A legtöbb kutatás viszont inkább azzal foglalkozik, hogy az oktatói identitáskonstruálás különböző mintázatait, sajátosságait mutassa meg. E kutatási terület fő fókuszai: 1) az oktatói/ szakmai fejlődés értelmezése; 2) a kezdő oktatók identitáskonstruálása; valamint egyre erősödő kutatási téma 3) az oktatói identitáskonstruálásának az egész oktatói életútban való vizsgálata, és a speciális szerepekhez kötődő elemzése. Az alábbiakban e terület eredményeit összegezzük röviden. Az oktatók szakmai fejlődésének különböző értelmezésével Åkerlind (2003, 2011) foglalkozott fenomenográfiai vizsgálataiban, és három jellegzetes utat azonosított: 1) a tanári komfortra, 2) a tanítási gyakorlatra, valamint 3) a hallgatói tanulásra fókuszáló szakmai fejlődési irányt. A tanári komfortra fókuszáló út a legkevésbé összetett tapasztalat, melynek során a szakmai fejlődés azt jelenti, hogy az oktatók egyre magabiztosabbak, s egyre kevesebb erőbefektetéssel tudják végezni a munkájukat. Mindez sem a tanítás, sem az oktató változásának tapasztalatát nem jeleníti meg. A tanításra fókuszáló szakmai fejlődés komplexebb tapasztalata már együtt jár a tanítás változásával, a tanítás tartalmának és a tanítási stratégiák gazdagodásával. Végül a legkomplexebb, tanulásra fókuszáló szakmai fejlődés az, amikor a fejődés célja a hallgatók tanulási tapasztalatainak javítása, átalakítva ezzel az oktatói és tanítással kapcsolatos elképzeléseket is.

A kezdő oktatók szakmai fejlődése és ennek támogatása egyre nagyobb jelentőséggel bír az intézményi gyakorlatokban. E terület kutatásai pedig szintén elmozdulnak a kezdő oktatói identitás sokféleségének feltárása felé. Remmik, Karm \& Lepp (2013) narratív vizsgálatukban 41 észt kezdő oktató identitás- és szakmai fejlődés értelmezését tárta fel. Négy fejlődési profil narratívát alakítottak ki: 1) a „jó tanár akarok lenni” narratívát, ahol az oktatók nagyobb változások nélküli, lépésről lépésre történő oktatói fejlődésről számoltak be 2) a „forradalmian oktatók" történetét, akik a szakterületükön megszokott tanítási hagyományokkal szállnak szembe 3) a „vajon elboldogulok az oktatói szerepben?” kétségekkel és bizonytalanságokkal terheltek narrativáját, ahol éppen a problémákkal való megküzdés, az ágencia okoz nehézséget, valamint 4) a sokféle szereppel rendelke- 
ző oktatók narratíváját, akiknél akár az egyetemen kívüli gyakorlati szakemberről, akár kutatóról van szó, jellemzően kevesebb a tanítás terhe, s hagyományosabb módon tanítanak.

Az oktatói életút egészében vizsgálta az oktatói identitásfejlődés szakaszait és mozgatórugóit Trautwein (2018) nyolc oktató tanulástörténeti epizódjainak elemzése segítségével. Három fő szakaszt és a szakaszokhoz kötődő katalizáló erőket azonosított. A három fő szakasz közül az első időszak középpontjában az oktatói sze rep felvállalása áll: például az oktatók még hallgatónak érzik magukat a konfliktusok, kritikák kihívást jelentenek az identitásalakulásukra, magabiztosságot kell sugallniuk, ami nagyon kimerítő számukra. A szakmai identitásalakulás legfőbb katalizátorai ekkor maguk a hallgatók, a velük való konfliktus vagy kritikus pillanatok meg élése. A második időszakban, amikor már több tanítási tapasztalatot szereztek az oktatók, elérkezik a tanári szerep letisztulásának időszaka. Itt már realisztikusabb képet alakítanak ki az oktatói szerepről, képesek elválasztani a személyes és szakmai ént, s oktatóként magabiztosnak érzik magukat. Az oktatói identitásfejlődés mozgatórugója ekkor elsősorban a képzésekhez, reflexiókhoz kapcsolódik. Végül a harmadik időszakban új, tanulásközpontú tanári szerep jelenik meg, ami összekapcsolódott azzal, hogy az oktatók elkezdtek járni egy tanulásközpontú képzésre. Legmeghatározóbb változást ösztönző erő ekkor az elméleti szempontokon alapuló reflexió és visszacsatolás.

Az identitáskonstruálást sajátos szerepekhez kötődően vizsgálta Nevgi és Löfström (2015). Narratív vizsgálatukban az oktatói fejlődésról szóló narratívákat dolgoztak fel, vizsgálva egyrészt, hogy négy fó identitásértel mezést találtak: a szerint, hogy feladataik alapján magukat inkább oktatónak/kutatónak vagy inkább oktatásfejlesztőknek látták, s hogy mindeközben mennyire jellemző rájuk, hogy reflektálnak a tanításra. Fontos ered mény, hogy a magukat inkább oktatásfejlesztónek vallók kevésbé reflektálnak saját tanításukra, helyette inkább a közösségi (kari, tanszéki) szintú szakmai fejlődésre fókuszálnak, vagy a felsőoktatás kutatására, ami ben nem erős az önreflexió.

Az oktatói identitásfejlődés kutatása összekapcsolódik a környezet támogató és hátráltató tényezőinek elemzésével. Van Lankveldék (2017) tematikus szintézisükben azt találták, hogy az oktatói identitásfejlődésre pozitívan hatnak a hallgatók, a szakmai fejlődéshez kötődő programok; negatívan pedig a felsőoktatás tágabb kontextusa. A kutatások arról tanúskodnak, hogy a hallgatók reakciói, visszajelzései kulcsfontosságúak az okta tók pozitív identitásalakulásában. Hátráltató tényezőként elsősorban a felsőoktatás nemzetközi és nemzeti kontextusa jelent meg. A negatív hatások két irányhoz kötődtek: egyrészt a neoliberális menedzsment kultúra erősödéséhez, másrészt az oktatás és kutatás közti feszültségekhez. A szakmai identitásalakulásra és fejlődés re legmegosztóbb módon a közvetlen munkakörnyezet hatott, hol pozitívan, hol negatívan. Ha ez a környezet kollegiális és támogató volt, akkor pozitívan hatott az identitásalakulásra, ha a tanszékek versengőek, ha a szervezet hierarchikus, ha bizalomhiány uralkodik, $s$ ha a kutatási tevékenységet előnyösebben értékelték, mint a tanítást, akkor inkább negatívan hatott.

\section{A kutatás célja és kérdései}

Nemzetközi szinten tehát újabban több kutatás is megjelent az oktatói identitás és szakmai fejlődés értelme zéseinek megragadására, differenciált értelmezésére, ugyanakkor a hazai kontextusban ez még feltáratlan terület, ami éppen egy olyan a szociálisan konstruált, társadalmilag-kulturálisan beágyazott jelenségnél, mint az identitáskonstruálás különösen lényeges adósság. A kutatások jellemzően különböző alcsoportokra figyelnek, például a kezdő vagy a pedagógiai képzéseken részt vevő oktatók körére, s ahogyan van Lankveld és kollégái (2017) is felvetették, még kevésbé feltárt, hogy a karrier különböző időszakában hogyan alakul az oktatói iden - 
titáskonstruálás - ami éppen kutatásunk egyik fő kérdése. A kutatási kérdéseink ezek alapján a következőképpen alakultak:

1. Az oktatói identitásalakulásban, a szakmai fejlődés során milyen mintázatok azonosíthatók? Milyen főbb időszakok, illetve fordulópontok láthatóak a szakmai életutakban? A szakmai fejlődésben képzési területenként találhatóak-e különbségek?

2. Az oktatók oktatói önértelmezéséhez, szakmai fejlődési időszakaihoz milyen tanítási elképzelések és jellegzetes tanulási módok kapcsolódnak?

\section{A narratív kutatás módszere és mintája}

\section{Az oktatói élettörténetre épülő interjú módszere}

2017 tavaszán oktatókkal élettörténeti és tematikus interjút vettem fel, de jelen tanulmány csak az oktatói élettörténetek feldolgozására fókuszál. Az élettörténeti interjú középpontjában a történetben elbeszélt élet vagy annak egy kitüntetett időszaka (Polkinghorne, 1995; Pataki, 2001; Clandinin, 2007) - például az elbeszélt oktatói élet áll. Az élettörténeti vagy egyes életszakaszokra fókuszáló interjúk segítségével feltárható az oktatói identitás és fejlődés narratív szerveződése, az identitás és fejlődés narratív koherenciára törekvő, időben értelmezett konstrukciói (Polkinghorne, 1995; László, 2005).

Az oktatói élettörténet során arra kérdeztem rá, hogy 1) hogyan kezdődött az oktatói életútjuk 2) azóta miben fejlődtek, változtak oktatóként, ennek milyen főbb mérföldköveit, valamint szakaszait észlelték 3) ezekben a szakaszokban hogyan tudott az oktatói tevékenységük kapcsolódni más kutatási, fejlesztési tevékenységekhez 4) valamint az oktatói karrier formális lépcsőfokai hogyan alakították a szakmai fejlődésüket. Az interjúk során a résztvevők maguk mesélték el szabadon az oktatói történetüket, s csak azután tértünk vissza egyes részek mélyebb értelmezésére. Az élettörténeti interjút kiegészítettem: az oktatói életről készített időszalag készítésével, valamint egy, az oktatói identitásváltozás szempontjából kritikus eseménynek a bemutatásával, elemzésével. Az interjúkat a kutató - aki maga is a felsőoktatási kontextusból érkezik - készítette, ami az inter júkészítés során a szakmai beszélgetés jelleget erősíthette fel. Az interjúkról hangfelvétel készült, melynek szövegét legépeltük az elemzéshez.

Az időszalag készítése gyakran képezi az élettörténeti interjúk vizuális kiegészítését. Főként akkor használják, ha a tágabb szociális kontextus értelmezése vagy az elbeszélt élet és az interjúalany életében kronologiku san történt események kapcsolata is meghatározó (Adriansen, 2012). Az időszalag célja a kutatásban az oktatói életút áttekintésének segítése volt, valamint annak elősegítése, hogy az oktatók szubjektív időkezelése öszszevethető legyen kronologikus történésekkel. Az oktatók az interjú azon pontján kapták meg az időszalagot, amikor vagy elakadtak a mesélésben, vagy amikor már befejezték oktatói élettörténetüket.

A kritikus esemény technikáját (Schluter, Seaton \& Chaboyer, 2008) az élettörténeti interjú végén használtam. Arra kértem a résztvevőket, hogy meséljenek el egy meghatározó eseményt, amikor úgy érezték, hogy ok tatóként jelentősen változtak. A kritikus események módszerét az oktatói gyakorlatok és „mögöttes” értelmezések mélyebb megértéséhez, valamint az oktatói élettörténet mérföldköveinek, fordulópontjainak konkretizálásához használtam. Az időszalag és a kritikus események elemzése is az élettörténetek elemzését egészítette ki, értelmezte, hitelesítette - önálló elemzésükre nem került sor. 


\section{A kutatás mintája}

A kutatás mintaválasztása célzott szakértői (Csíkos, 2009), olyan oktatókat és intézményeket kerestünk, akik az oktatás iránt érdeklődnek, elkötelezettek, tenni vágyóak. Az adatgyűjtés során először egy-egy oktatót találtunk meg az adott területről, akitől aztán a hólabda elve alapján további, az oktatásra, tanulásra nyitott kollégákat értünk el. Az adatgyưjtés során két fő szempontra figyeltünk: egyrészt hogy különböző, jellegzetesen eltérő képzési területek oktatóit szólítsam meg, másrészt hogy minden képzési területről három jellegzetes oktatói csoportot vonjak be a mintába. A mintába a következő négy képzési terület került be: 1) a pedagógusképzés, neveléstudomány 2) gazdaságtudomány 3) orvostudomány, valamint 4) az állam- és jogtudomány területe. Minden terület az alkalmazott tudományok köréből került ki - ahol feltételeztük, hogy az oktatásban számos kihívás, változás jelent meg az elmúlt időszakban. Ezen belül viszont a puha és kemény tudományok képviseletére is figyeltünk (Vö: Becher, 1994). Minden szak- és tudományterületről három oktatót választottunk: egy kezdő oktatót, egy tapasztalt oktatót, valamint egy olyan tapasztalt oktatót, akinek jelenleg meghatározó vezető szerepe van a képzés, oktatás alakításában, fejlesztésében (pl. képzésfejlesztő, szakfelelős, tanulmányi fele lős). A kezdő oktatók körébe alapvetően a 10 évnél kevesebb tapasztalattal rendelkezők kerültek, de volt, hogy az is számított, hogy egy adott kontextusban ki számított fiatalabb kollégának, akár úgyis, hogy adott esetben a nem csak oktatói státuszban tanított időszak 10 évnél is hosszabb volt. Az adott terület három oktatója mindig ugyanabból a felsőoktatási intézményből került ki, s arra is igyekeztünk figyelni, hogy ha lehet, egy intézethez, képzési területhez tartozzanak. Összesen tehát 12 oktatóval készült interjú, a háttéradatokat részletesebben lásd az 1. számú táblázatban. A minta több felsőoktatási intézményből származott, s bár nyilván az intézmények sajátos szervezeti kultúrával rendelkeznek, számos közös vonásuk is érzékelhető, amelyek közül fontos megemlíteni: mindegyik állami fenntartású, nagy hallgatói létszámmal dolgozó, kutatást is folytató felsőoktatási intézmény. 


\begin{tabular}{|c|c|c|c|c|c|c|}
\hline Oktató & Képzési terület & $\begin{array}{c}\text { Felsőoktatási karrier } \\
\text { kezdete ösztöndíjas } \\
\text { doktoranduszként vagy } \\
\text { tanársegédként } \\
\text { ( }{ }^{*} \text { hallgatóként is már } \\
\text { bevonódtak az } \\
\text { egyetemi feladatokba, } \\
\text { pl. demonstrátorként) }\end{array}$ & Neme & $\begin{array}{l}\text { Hallgatóként } \\
\text { kezdett oktatni }\end{array}$ & $\begin{array}{c}\text { Doktoran- } \\
\text { duszként } \\
\text { kezdett } \\
\text { oktatni }\end{array}$ & $\begin{array}{l}\text { Jelenlegi } \\
\text { beosztása }\end{array}$ \\
\hline PA & Pedagógusképzés ${ }^{4}$ & $\begin{array}{l}2008 \\
\text { (doktoranduszként)- }\end{array}$ & Nő & - & + & Tanársegéd \\
\hline GA & Gazdaságtudomány & $\begin{array}{l}\text { *2008-, } 2011 \\
\text { (doktoranduszként)- }\end{array}$ & Nő & - & + & Tanársegéd \\
\hline OA & Orvostudomány & $\begin{array}{l}2009 \\
\text { (doktoranduszként)- }\end{array}$ & Nő & - & + & Tanársegéd \\
\hline JA & $\begin{array}{l}\text { Állam- és } \\
\text { jogtudomány }\end{array}$ & $\begin{array}{l}\text { *2002-, } 2004 \\
\text { (doktoranduszként) - }\end{array}$ & Férfi & + & + & Adjunktus \\
\hline PB & Pedagógusképzés & 1994 (tanársegédként) - & Nő & - & - & Docens \\
\hline GB & Gazdaságtudomány & $\begin{array}{l}\text { *2000-, } 2002 \\
\text { (doktoranduszként) - }\end{array}$ & Férfi & + & + & Adjunktus \\
\hline OB & Orvostudomány & $\begin{array}{l}\text { *2000-, } 2004 \\
\text { (doktoranduszként) - }\end{array}$ & Férfi & + & + & Adjunktus \\
\hline$J B$ & $\begin{array}{l}\text { Állam- és } \\
\text { jogtudomány }\end{array}$ & $\begin{array}{l}\text { *1972-, } 1980 \\
\text { (tanársegédként) - }\end{array}$ & Nő & + & - & Docens \\
\hline PC & Pedagógusképzés & 1996 (tanársegédként) - & Nő & - & - & Docens \\
\hline GC & Gazdaságtudomány & $\begin{array}{l}\text { *1989-, } 1993 \\
\text { (tanársegéd) }\end{array}$ & Férfi & - & - & Docens \\
\hline OC & Orvostudomány & $\begin{array}{l}\text { *1994-, } 1996 \\
\text { (doktoranduszként) - }\end{array}$ & Férfi & + & + & Docens \\
\hline JC & $\begin{array}{l}\text { Állam- és } \\
\text { jogtudomány }\end{array}$ & $\begin{array}{l}\text { *1984-, } 1986 \\
\text { (tudományos } \\
\text { segédmunkatársként) - }\end{array}$ & Nő & + & - & Docens \\
\hline
\end{tabular}

1. táblázat. Az interjúkban részt vevő oktatók föbb háttéradatai

\section{A narratív elemzés}

Az interjúk narratív megközelítésű elemzése elősegíti azt, hogy olyan témák kerüljenek elő a szakmai identitás, fejlődés és tanulás kapcsán, amelyeket az oktatók maguk tartanak fontosnak (Patton, 2002, Remmik et al., 2013). A történet narrátorai a tapasztalatokat időbeli és térbeli struktúrába szervezik, de az időbeli szekvenciák nem feltétlenül jelentenek lineáris fejlődést. A narrátor az előnyös identitását mutatja be, ugyanakkor az időbeli szerveződés, a fordulópontok azonosítása a történetekben éppen az identitáskonstrukció jelentős változásait ragadhatja meg az alakulás folyamatában (Riessman, 2001). Ezek alapján narratív elemzésünkben elő-

4. A mintába a pedagógusképzés területéről csak a neveléstudomány képviselői kerültek, ezzel is figyelve arra, hogy az adott képzési terület minél homogénebb csoportját tudjuk bevonni a kutatásba. 
ször az interjúkban megjelenített oktatói önértelmezéshez, az identitáskonstrukció változásához kötődő fordulópontokat és az ezek közti időszakokat azonosítottuk. Majd az oktatók értelmezései által kirajzolódó oktatói identitás és fejlődés szakaszaihoz kötődően elemeztük a tanulás és ágencia sajátosságait. Végül az egyes időszakok hasonló és jellegzetesen eltérő mintázatait azonosítottuk, összevetve a kezdő, tapasztalt és tapasztalt vezetői gyakorlattal is rendelkező oktatók történeteit, valamint az egyes csoportok élettörténetein belüli retrospektív, adott időszakokhoz kötődő önértelmezéseket.

\section{Eredmények}

Az oktatói alidentitás: oktatói önértelmezések és változásaik

A szakmai fejlődés szakaszai erőteljesen kapcsolódnak ahhoz, hogy hogyan értelmezik magukat mint oktatókat az interjúalanyok, s ezáltal mik azok a prioritások, amelyek előtérbe kerülnek az adott időszakban. Az identitás értelmezések változásai egy-egy fordulóponthoz kötődnek, azt lehet mondani, hogy az adott fordulópont értelmezi azt, hogy az oktató hogyan gondolkodott magáról a fordulópont előtt és után. Tehát elemzésünkben az oktatói önértelmezések változását az oktatók által azonosított fejlődési szakaszokhoz, a szakaszok közti kisebb vagy jelentősebb fordulópontok értelmezéséhez kötjük. Eredményeink bemutatásakor elsősorban az oktatói élettörténetekben megmutatkozó közös jellemzőkre fókuszálunk, s azokat a három oktatói csoport szerint mu tatjuk be: kezdő, tapasztalt, valamint tapasztalt oktatók vezetői gyakorlattal. Az eredmények áttekinthetőségét az 1. számú ábra segíti. 


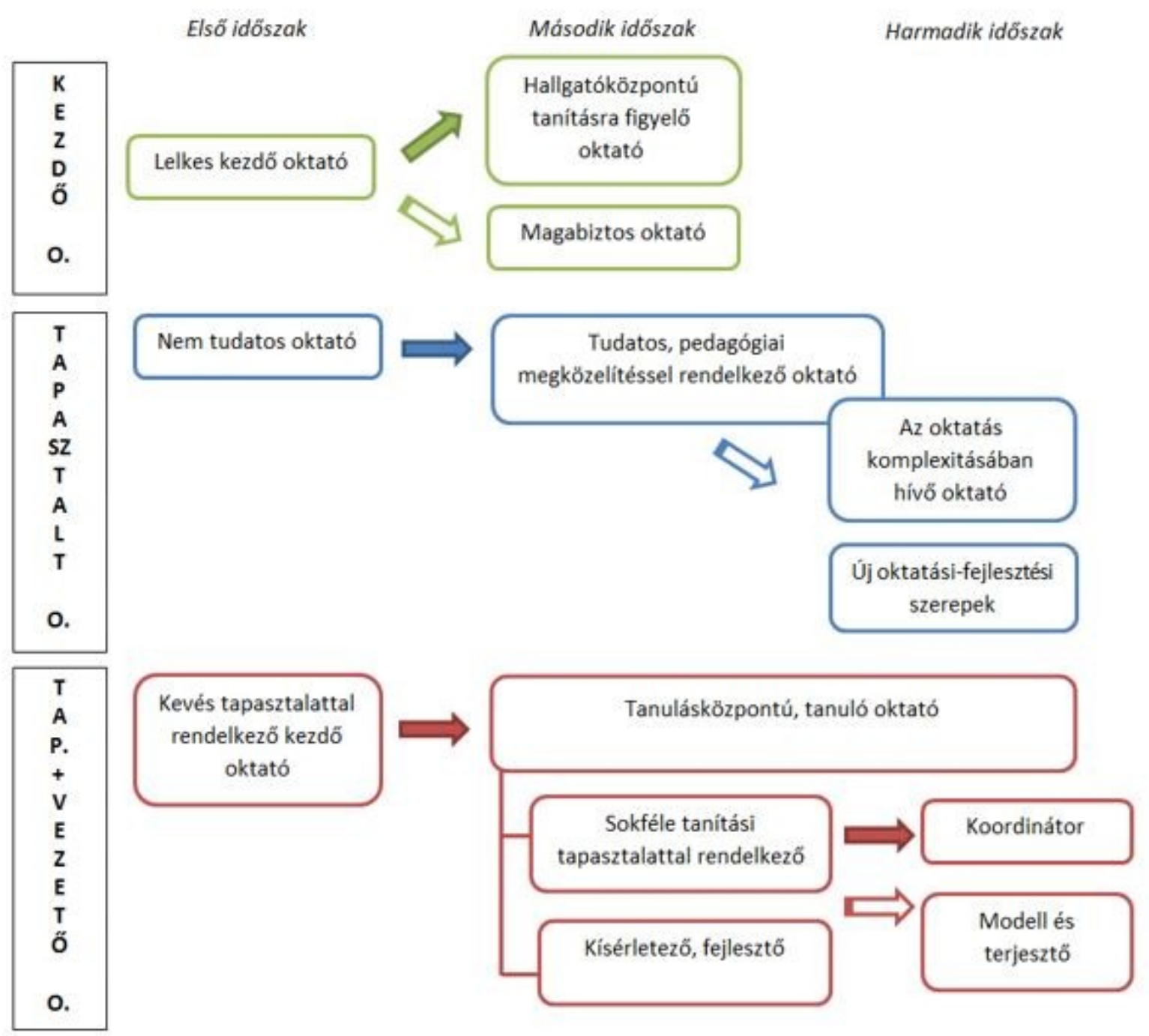

1. ábra: Az oktatók szakmai fejlődésének, tanulásának sajátosságai a különböző fejlődési szakaszokban (Az ábrán a színezett nyíl a radikális, míg az üres nyíl a kisebb léptékü változásokat, fordulópontokat jelöli)

\section{A kezdő oktatók}

A kezdő oktatók kb. 10 vagy egy esetben még annál is több éve dolgoznak a felsőoktatásban, ami annak is a jele, hogy ahhoz, hogy valaki már ne doktoranduszként oktasson, hosszabb időnek kell eltelnie. Ebben az időszakban az oktatói történetekben jellemzően három fö önértelmezés jelenik meg: 1) a lelkes kezdő 2/a) a hall gatóközpontú tanítást gyakorló oktató és $2 / b$ ) a magabiztos oktató. A két utóbbi oktatói kép összefonódva, az elbeszélt történetekben egymással nagyjából párhuzamosan, bár az egyes élettörténetekben különböző hangsúlyokkal jelent meg.

A lelkes kezdő oktató képében fontos, hogy az oktatók kiemelik, hogy szeretnek tanítani, hogy lelkesek, pozitív érzelmekkel viseltetnek a tanítás iránt: „szeretek tanítani [...] szeretem csinálni, és hogy megy is, tehát jó viszszajelzéseket kaptam, tehát hogy jó vagyok benne, úgy túnt" (JA). Továbbá reflektálnak arra, hogy fontos számukra az oktatói szerep: „szívesen kipróbálja magát az ember oktatóként” (KA). E lelkes kezdő oktatói időszakban van, 
aki a tanítást inkább önmegvalósításként élte meg (JA), s van, aki inkább arra figyelt, hogy kezdetben hogyan tud megfelelni az oktatói közösség elvárásainak (OA, KA).

A jelentős fordulópontot történeteikben a hallgatókra való odafigyelés, előzetes vagy éppen elérendő tudásukra való reflexió váltja ki. „Nem sikerült úgy megragadni a hallgatók figyelmét, valami nem jött össze” (KA), „jobban reflektálok arra, hogy ők [a hallgatók] mit szeretnének, illetve, hogy ők mit gondolnak. [...] Sokkal jobban építek már rájuk. Sokkal jobban figyelek arra, hogy ők is szerepeljenek, előtérbe kerüljenek." (JA) A hallgatóközpontú tanításra figyelő, azt gyakorló oktató képéhez erőteljesen kötődnek azok a pedagógiai gyakorlatok, amelyek a hallga tók bevonására építenek (KA), az interaktív tanulásszervezéshez (JA), az esetfeldolgozás gyakorlatához (KA), a hallgatók egymástól tanulásának lehetőségeihez (PA) vagy éppen konzultáció megszervezéséhez (OA) kötődnek, valamint a hallgatói nézőpont megjelenítésére (PA, OA) figyelnek. Jellemzően ezek a hallgatóközpontú megoldások a tanórai tanulásszervezéshez kapcsolódnak. Ugyanakkor jelzésértékű, s további vizsgálatot igényel, hogy a tanórai tanulásszervezés megújítására figyelő gyakorlat az egyes szakterületekre jellemző tanítás (Vö: Shulman 2005) következtében felerősítheti a tanórai tanulásszervezés és tervezés, vagy éppen a tanórai tanulásszervezés és értékelés/vizsga kapcsolatát. A pedagógusképzés, neveléstudomány területén tanító kezdő oktató a hallgatóközpontú tanulásszervezést összekapcsolja a tervezés komplexitásával, hosszú és rövid távú, az egész pedagógus-életpályát figyelembe vevő tervezés gyakorlatával. A jog oktatása esetében a hallgatóközpontú, interakcióra épülő tanulásszervezés a vizsgák, az értékelési alkalmak esetében is megjelenik: „ez is az interakcióról szól szerintem, hogy az interakcióból derül ki, hogy valaki mit tud, vagy mit értett meg az egészből, meg hogy hogyan gondolkodik” (JA). Hallgatóközpontú oktatóként általában a sikerélményeiket emelik ki: „amikor először sikerült egy ilyen, az úgy föltöltött engem, és akkor úgy mentem be óráról órára, hogy fúúu, igen, ez most akkor jó lesz, és akkor tényleg azt éreztem a hallgatókon is, hogy igen, ez tetszik nekik" (KA). Fontos, hogy a hallgatóktól pozitív visszajelzéseket kapnak a megváltoztatott tanításukra (KA, OA, PA). Ugyanakkor e hallgatóköz pontú gyakorlatok kapcsán a sikeresség hullámzó jellege is megfogalmazódik (PA, KA), az oktatók többé és kevésbé sikeres oktatási időszakokat is érzékelnek.

Az oktatói élettörténetekben a másik, az előbbivel többnyire párhuzamos, de legalábbis az élettörténetek alapján időben nem jól elkülöníthető változás, amikor a lelkes kezdő oktatóból magabiztos oktató válik. Ebben az oktatói identitásfejlődési folyamatban nem lehetett éles fordulópontokat azonosítani, inkább a fejlődés fokozatossága jelent meg, pl. „a kezdő oktatói sajátosságok levetkőzése [...] ez egy beleszokás” (PA). Ennek a magabiztos oktatói szerepnek az elérése az élettörténetekben a következőkben öltött testet: „most már fel tudom azt mérni, hogy mire mennyit kell készülnöm, hogy mivel mennyi dolgom van egy óra után” (PA), „sokkal magabiztosabban adok elö. Most már nyilván látom, hogy mik a kritikus problémák a hallgatóknál, és akkor inkább arra koncentrálok” (OA), „a hallgatók kihasználják, vagy nem úgy élnek ezekkel a lehetőségekkel, meg a fejedre nőnek, akkor rájössz, hogy lehet, a határokat jobban tartani kéne" (KA).

\section{A tapasztalt oktatók}

A tapasztalt oktatók önértelmezése kapcsán három fő időszakot lehetett azonosítani. Élettörténetük első oktatói időszakában magukat nem tudatos kezdő oktatónak írták le. Ezt váltja fel a második időszakban a tudatos, markáns oktatási elképzeléssel rendelkező oktató képe. Végül oktatói élettörténetük következő - de sokszor az előzővel részben átfedésben lévő - időszakában megerősödik a tanításról való komplex és rendszerszerū gondolkodás, s ezáltal az oktatói önértelmezésük is egy, az oktatás komplexitására építő oktatói képhez kötő dik. 
Oktatói élettörténetük első időszakában a nem tudatos oktató képe gyakorlatilag hiányállapotként jelenik meg: összehasonlítva a következő időszak oktatói önértelmezésével az látszik, hogy visszatekintve akkor még mennyire nem gondolkodtak tudatosan és mélyen a tanításról. „Hogy őszinte legyek, nem is gondolkodtam soha azon, hogy az egyetemi oktató honnan tudja azt, amit oktat. [...] /nevetés/ egyáltalán nem volt tudatos ez. [...] most már bevallhatom, hogy teljesen naivan gondoltam, ami érdekes lehet, azokat tanítottam” (PB), „az oktatásnak valamiféle érési folyamata az biztos, hogy zajlott, szóval nem volt meg a nagyon tudatos pedagógiai háttér vagy pedagógiai gondolkodás" (KB). Az oktatói visszatekintésekben erről az időszakról inkább röviden beszélnek az oktatók, és bár van, akinél előkerül a lelkes kezdő oktató képe, aki igazán szeret tanítani, a hangsúly mégsem ezen van.

A tudatos, markáns oktatási elképzeléssel rendelkező oktató képe már sokkal erőteljesebben, kifejtettebben jelenik meg az élettörténetekben. Az oktatók egyrészt magát a tudatosság fontosságát emelik ki, másrészt azt a tudatosan kialakított, vállalt oktatással kapcsolatos elképzelést, amit megformáltak már erre az időszakra. Már nem csak lelkesedésból, hanem tudatosan, a tudományos alapok megismerésével is foglalkoznak az oktatással (OB). Egy lassabb tanulási, tudatosítási folyamat során oktatói önértelmezésükben meghatározóvá válnak bizonyos oktatási megközelítések: a tevékenységközpontú megközelítés; a gyakorlati, alkalmazásorientált megközelítés; flexibilis, személyre szabott pedagógia, fejlesztő értékelés. E megközelítések van, hogy egy jól körülhatárolható, expliciten említett elméleti koncepcióhoz kötődnek: „magamról mindmáig úgy gondolkodom, hogy tevékenységekben, tevékenységközpontúan gondolkodom az oktatásról. [...] tevékenység még olyan értelemben is, hogy az élményt is belevéve" (PB), de az is lehetséges, hogy kevésbé expliciten, ugyanakkor részletesen indokolva jelennek meg, olyan pedagógiai hitvallásként, ami a saját tanításértelmezés lényegét próbálja megragadni: „Jelentős tudatosodás vagy fordulat, ha lehet így fogalmazni. Aminek egyszerüen az a lényege, hogy arról a pontról, és ezt elkezdtem tudatosítani, [...] hogy mi az, amit a hallgatónak tudnia kell, meg mi az, amit a hallgató nem tud, el indultam abba az irányba, hogy azt nézzem, hogy mi az, amit a hallgató csinál, mi az, ami abban értékes" (KB). Ebben az oktatóképben tehát fontossá válik az, hogy a tanítási tevékenység mögött koncepció, elméleti alapok, átgondolt elképzelésrendszer áll. Ebben az esetben nem a hallgatóközpontú tanítási módszerek, tevékenységek azok, amik meghatározóak az önértelmezés alakításában - mint ahogyan a kezdó oktatók történeteiben láttuk -, hanem az az elképzelésrendszer, tanítási megközelítés, pedagógiai gondolkodásmód, ami a gyakorlat mögött meghúzódik.

Amíg a nem tudatos és a tudatos oktatókép közt markáns változást érzékelnek az oktatók; addig a tudatos, meghatározó pedagógiai elképzeléssel rendelkező oktató képe, valamint az oktatás komplexitásában hívő oktató értelmezése egymásba is fonódik; az utóbbi ugyan általában később jelenik meg az élettörténetben, de csak bővíti, nem pedig radikálisan átrendezi a korábbi oktatói önértelmezést. Az oktatás komplexitásában hívő oktató fő jellemzője, hogy kilép abból a keretből, hogy a tanítást, az oktatói munkát egyéni szinten értelmezze. Elmozdul egyfelól az egyes tanórákra, kurzusokra fókuszálás helyett a komplex képzési programok tapasztalatáig; másfelől az egyéni oktatói munka felől a kollektív oktatói lét felé. A képzési program szintjének megtapasztalásáról, a hallgatók komplex tanulási tapasztalatának fontosságáról, az oktatók munkájának közös hatásairól és a közös hatás felismerésének szükségességéről tanúskodnak az alábbi idézetek: „Jobban érzékelem azt a komplexitást, azt a komplex rendszert, aminek csak egy nagyon picike része az, amit én csinálok, [...] jobban érzem azt az erőteret, amiben ez végbe megy” (PB). „Jelentős hangsúlyeltolódások lehetnek akár ugyanabban évben két előadás közt [...] Szóval nincsen ilyen szempontból, egy átfogó koncepcionális íve a dolgoknak. Igény már van rá, [...] hogy legyen valami, hogy akkor már hangolják mégiscsak jobban össze a tárgyakat” (OB). „A folyamatos építkezés eredmé- 
nyeképpen mostanra szerintem egy rendkivül jó képességü, és nagyon összetartó tanszék jött létre”, ahol közösen gondolkodnak a tematikák, képzési anyagok újraszervezésén (JB).

Új oktatási, fejlesztési szerepek is kapcsolódnak ehhez az időszakhoz, amelyek lényeges szerepet játszanak az oktatói identitás értelmezésében, s jellemzően hozzájárulnak ahhoz, hogy az oktatási, oktatói tevékenységek ne csak az egyes tanórákhoz, kurzusokhoz kötődjenek, hanem tükrözzék az oktatói munka komplexitását is. Megjelenik a programfejlesztői (PB, JB), az intézményfejlesztői szerep (KB), az oktatás tudományos megközelítésének terjesztőjének szerepe (OB). A felsőoktatási intézményen belül ezek elismertsége nem minden esetben formalizált, jellemző a félig formalizált vagy éppen formalizálódó szerep is. Például intézményfejlesztőként „időnként kitalálok valamit, azt csinálom aztán pár évig, ha van kedvem, meg ha van rá igény, aztán ha meg nincs, akkor ezek elhalnak" (KB).

\section{Tapasztalt oktatók vezetői gyakorlattal}

Ez az oktatói csoport is több jelentős változást észlelt az oktatói önértelmezésében, oktatói élettörténetében: a kevés tapasztalattal rendelkező kezdő oktatói időszak után változást jelent a tanulásközpontú szemlélet megerősödése, és ezzel együtt a tanuló oktató képe. Ezen belül és a további oktatói élettörténetben viszont már eltérő utak, oktatói önértelmezések jelennek meg.

Kezdő oktatói identitásuk legfőbb jellemzőjének a kevés tapasztalatot és ezzel kapcsolatos bizonytalanságot látják. Ahogyan a kezdő oktatói csoportnál, itt is megjelenik a lelkesedés, a tanítani vágyás, de az is, hogy „nem kezeltek oktatóként" a hallgatók. Mindezzel pedig együtt jár, hogy visszatekintve félelmeket, kudarcokat és sikereket egyaránt kötnek ehhez az időszakhoz.

A tanulásközpontú szemlélettel rendelkező, tanuló oktató képe egy olyan új időszakot jelöl, ahol egyfelől a hallgatói tanulással kapcsolatos szemléletmódjuk átalakul, másfelöl hangsúlyossá válik, hogy ők maguk is tanulják, hogyan lehet a hallgatók tanulását támogatni. Ebben a tanulásszemléletben erős, hogy a tanulás lassú folyamat, hogy az előzetes tudásra építeni kell, hogy világosan kell látni a tanulás lépéseit, a képzési cél szempontjából meghatározó elemeit, a hallgatók tanulás szempontjából fontos jellemzőit - s végső soron erre kell építeni a tanítást. Ahogyan az oktatók fogalmazzák meg: „Sokkal nyitottabbá váltam, azt gondolom, arra, hogy másoknak is van tanulási útja, és hogy onnan kell indulni, ahol ő tart” (PC). „Ott kialakultak nálam a súlypontok, hogy mi az, ami nekem ahhoz kell, hogy később tudjak rá építeni. [...] addig mindent le akartam nyomni a hallgatónak a torkán. És állatira meg is voltam sértve, hogy nem akarta lenyelni ezeket, tehát úgy éreztem, hogy ő nem tesz bele eleget" (JC). „Fokozatosan vettem észre azt a nyilvánvaló dolgot, hogy nagyon más az a pedagógia, amit akár a korosztály, akár [a hallgatói] élettapasztalatok, munkahelyi tapasztalatok” miatt használni lehet (KC). „Szóval azt is tanulni kell, hogy mi várható el egy hallgatótól [...] a cél az, hogy a hallgató az összefüggéseket nagyjából megértse, és akkor bizonyos részletek fölött el lehet siklani a vizsgáztatónak is, meg a hallgatónak is. És ezt tanulni kell, tehát mondhatnám azt, hogy kevésbé lesz szigorú az ember [...] de valójában, azt hiszem, a szemlélet változik meg" (OC). E tanulásközpontú szemlélethez erősen kapcsolódik az, ahogyan az oktatói önértelmezésben magának a rendszeres, folyamatos szakmai tanulásnak is meghatározó szerepe lesz: „rengeteg olyan helyzetbe kerültünk, egyre mélyebbekbe, amiben az oktatói oldalt nagyon kellett erősítenünk, mert hogy én magam is úgy ítéltem meg a helyzetet, hogy nem megy zsigerből” (PC). A tanuló oktató képénél különösen meghatározó, hogy kifejezetten nemcsak a kezdeti időszakra vonatkozik, hanem többségében az egész élettörténeten végigvonul a tanulásra való nyitottság.

A tanulásközpontú szemléletű, tanuló oktató képéhez két lényeges, az egyes élettörténetekben eltérő hangsúllyal megjelenő önértelmezés kapcsolódik: a sokféle tanítási tapasztalattal rendelkező oktató, valamint a 
kísérletező, fejlesztő oktató. A sokféle tanítási tapasztalat meghatározó az oktatói önértelmezésekben: különböző korosztályok vagy dolgozó felnőttek tanítása, a sokféle kurzustípusban, sokféle képzésben, vagy akár több felsőoktatási intézményben való tanítás. E sokféle tanítási tapasztalatot jelentősnek tartják a tanuló oktató önértelmezésükben. A kísérletező, fejlesztő oktató képében szintén összefonódik a tanulásközpontú szemlélet és a tanuló oktató képe, de itt már nem csak a változó helyzetekre, kihívásokra reagálnak az oktatók, hanem maguk is aktívan keresik az új tanulásközpontú megoldásokat. A pedagógiai kísérletezés és fejlesztés is kapcsolódik a kollegiális együttmúködéshez, a közös munkához.

Ez az oktatói csoport az egyes oktatói időszakok közt nem lát igazán radikális változásokat, inkább mindegyiket egy következő lépcsőfoknak tartja. Ez alól kivételt jelent a leggyakrabban formálisan is elismert szerep pé váló szak-, illetve tanulmányi felelősség. Itt többen különösen nagy váltást észlelnek, s megfogalmazzák azt, hogy ez az új szerepkör a tanulásközpontú oktatói identitásukat is gyengíti. „olyan feladatok tömegét kapom, ami nem feltétlenül engedi azt a fajta elmélyülést, ami az ilyen oktatási tevékenységhez szükséges" (PC).

Bár mindenki rendelkezik valamilyen, az oktatáshoz kötődő vezetői szereppel - szakfelelős, tanszékvezető adott képzési terület gondozásával, tanulmányi felelős -, alapvetően két markáns szakmai fejlődési út látható. Az egyikben e szerepek kapcsán is az oktatói modell és ehhez kötődő, másokat támogató szerep erősödik fel, a másik irányban pedig inkább a koordinátor, oktatásszervezői szerep. Mindkét iránynál (három oktatónál) különösen erős a mások tanulását támogató funkció, lehet az egyéni segítségnyújtás, a tanulásközpontú oktatással kapcsolatos tudás tervezett, szervezett megosztása, de egyáltalán a horizontális, kollégák közti tanulás elősegítése, szakmai múhelyek erősítése is. Ilyen értelemben pedig kifejezetten az újitások kezdeményezőivé és terjesztőivé válnak: „innovativ és kockázatvállaló újitásoknak [pl. teamekben tartott szakszeminárium] a kezdeményezője és együttmüködéseknek a szervezője [lettem]" (KC).

Jellemzően azok válnak modellekké, támogatókká, akik korábban már kísérletező, fejlesztő oktatókként is múködtek. „Mi valami olyasmit tudunk az egyetemi oktatásról, amit tán más nem tudott azokon a területeken” (PC), „egyenként mentem minden kollégához, és tanítottam meg óket az ETR-re, meg a Moodle-re” (JC). Ezek az oktatók erősek a kollégák személyes támogatásában. A koordinátor, oktatásszervező szerep önértelmezésekor pedig kiemelendő e szerep tágassága, gyakorlatilag: „a legrutinszerübb munkáktól, a leginkább kezdeményező újitó stratégiáig mindent" (KC) ők végeznek. És éppen e szerephez kötődő sokféle tevékenység az, ami elveszi a saját kutatói, sőt, oktatói fejlődéstől az időt. Ráadásul e szerepértelmezésben nemcsak a feladatok sokfélesége jelent nehézséget, hanem e szerepkör mások számára szinte láthatatlan volta.

A szakmai fejlődés és tanulás sajátosságai az oktatók élettörténeteiben, oktatói fejlődésük egyes szakaszaiban

Az élettörténetekben megjelenő egyes fejlődési szakaszokhoz, a hozzájuk kapcsolódó oktatói identitásképek alakulásához jellegzetes tanulási módok, utak, támogatási formák kapcsolódhatnak. Továbbá a szakmai fejlődési időszakokhoz kötődően lényegi kérdéssé válik az egyéni és kollektív oktatói ágencia sajátos megjelenése is. Az alábbiakban tehát az egyes oktatói fejlődési szakaszokhoz kötődően a tanulás jellegzetes módjait és az ok tatók tanulásának támogatási formáit, meghatározó szereplőit azonosítom, valamint az oktatói ágencia megélésének lehetőségeit. A könnyebb áttekinthetőség érdekében a fő eredményeket a 2. számú táblázat rögzíti. 


\begin{tabular}{|c|c|c|c|}
\hline Kezdő oktatók & $\begin{array}{l}\text { (a) Formális támogató } \\
\text { rendszer, ami a fokozatos } \\
\text { bevonódásra épít } \\
\text { (b) Nagy hatású mesterek és } \\
\text { közösség }\end{array}$ & $\begin{array}{l}\text { (a) Saját tapasztalat és a } \\
\text { hallgatók munkájának, } \\
\text { visszajelzéseinek } \\
\text { elemzése } \\
\text { (b) Új fejlesztési-oktatási } \\
\text { feladatok és } \\
\text { kísérletezés }\end{array}$ & \\
\hline $\begin{array}{l}\text { Tapasztalt } \\
\text { oktatók }\end{array}$ & $\begin{array}{l}\text { (a) Mozaikos tanulási } \\
\text { tapasztalat: oktatói minták } \\
\text { utánzása, próba-szerencse, } \\
\text { kollégákkal beszélgetés, az } \\
\text { oktatói bevonódás } \\
\text { formalizált támogatása, } \\
\text { magas elvárások }\end{array}$ & $\begin{array}{l}\text { (a) Átgondolt kísérletezés, } \\
\text { fejlesztés egyéni } \\
\text { szinten } \\
\text { (b) A saját egyetemen } \\
\text { kívüli tapasztalatok } \\
\text { gyűjtése, } \\
\text { együttműködések }\end{array}$ & $\begin{array}{l}\text { (a) Közös } \\
\text { fejlesztésekből, } \\
\text { együttműködésből } \\
\text { való tanulás - magas } \\
\text { ágenciával, } \\
\text { felelősséggel }\end{array}$ \\
\hline $\begin{array}{l}\text { Tapasztalt } \\
\text { oktatók vezetői } \\
\text { gyakorlattal }\end{array}$ & (a) Saját tapasztalati tanulás & $\begin{array}{l}\text { (a) Tapasztalati tanulás } \\
\text { (b) Kísérletezés, fejlesztés } \\
\text { (c) Kölcsönös tanulás, } \\
\text { együttmüködések, } \\
\text { szakmai } \\
\text { közösségek/műhelyek }\end{array}$ & $\begin{array}{l}\text { (a) Mások tanulásának } \\
\text { támogatása } \\
\text { (b) Átmeneti időszak a } \\
\text { vezetői szerep } \\
\text { kapcsán: átadás- } \\
\text { átvétel }\end{array}$ \\
\hline
\end{tabular}

\section{Kezdő oktatók}

Az élettörténetek alapján az oktatók szakmai tanulása, a fejlődés támogatása a kezdő oktatók esetében a dok toranduszi időszakhoz kötődik, bár van egy olyan kezdő oktató is, akinek az oktatóvá válása már hallgatóként megkezdődik, mivel már az egyetemi felvételi előkészítőn is tanított (JA). A lelkes kezdő oktatói időszak tanulására, a szakmai fejlődés támogatására jellemző - leszámítva a pedagógusképzési területet -, hogy az adott szakterületen hagyományos formákra épülő, többé-kevésbé formalizált, oktatói szocializációt szolgáló rendszerek, forgatókönyvek alakultak ki. Ezek a támogatási formák arra szerveződnek, hogy az adott szakterület oktatásába fokozatosan vezessék be a kezdő oktatókat: a könnyebb, periferikus, kevésbé meghatározó oktatási tevékenységektól az egyre fontosabb, komplexebb tevékenységekig (Vö: legitim periferikus részvétel, Wenger 1998). Ebben a támogatórendszerben a kezdeti lépcsőfokot mások óráinak hospitálása (JA, KA, PA), kisebb segédoktatói feladatok ellátása (pl. vizsgák javítása, felügyelete /JA/), kidolgozott tananyagok, segédanyagok megosztása a kezdő oktatóval (KA), valamint egy tapasztalt oktató mellett való oktatói tevékenység (OA) megkezdése jelenti. A következő lépcsőfok minden oktató esetében az egyedül történő, önálló tanítás. Kezdetben jellemző, hogy szemináriumi vagy gyakorlati órák tartásába vonják be az oktatókat, van, hogy inkább választható, s inkább alapszakos tantárgy oktatásába (KA). A következő általános lépcsőfok, hogy a kezdő tanárok kurzusainak mennyisége nő, s hogy az adott szakterületen egyre meghatározóbb, nehezebbnek tartott kurzustípusokat is tarthatnak: az orvosi területen például konzultációt, majd idegen nyelvú kurzust, a közgazdaságtudományi területen előadást.

A tervezett, szervezett fokozatos oktatói bevonódásra épülő támogatási rendszerek jellemzően a kezdő oktatók egyirányú támogatására épülnek, s ezáltal kevés teret hagynak a kezdő oktatók kezdeményezésére, ágens viselkedésére. Az oktatók szakmai tanulásának kölcsönössége ritkán jelenik meg, viszont ha igen, akkor kifejezetten pozitívan. Találunk példát a fiatal lelkes kezdők egymástól tanulására (KA), de a tapasztalt oktató- 
val közös tanulásra is: „együtt csináltunk végig egy kurzust úgy, hogy ő is jött hozzám órát nézni, én meg ugye jártam egyébként is hozzá sokat, és végignéztük az óravázlataimat is, és utána ezt át is beszéltük, tehát az elején ez nagyon sokat segített" (PA).

Ebben a lelkes kezdő oktatói időszakban a szakmai tanulás szempontjából jelentős azoknak a mestereknek a hatása (KA, PA, JA), akik már az egyetemi pálya választására is nagy hatással voltak. Valamint előkerül a szakmai közösség támogató szerepe is, bár ez sose csak az oktatói szerephez kapcsolódik (JA, KA): „ez a közeg tetszett meg, a munka, meg az a mentalitás, ahogy itt dolgozni lehetett, és a csapat, meg magának az intézetnek a szellemisége - ez tartott végül is itt" (KA).

A hallgatóközpontú tanításra fókuszáló időszakban már jellemzően eltűnnek ezek a formális támogató rendszerek, forgatókönyvek. Alapvetően két dominánsnak mondható tanulási mód erősödik fel, jelenik meg: (1) az egyik a saját tanítási tapasztalat elemzése, reflexiója összekapcsolódva a hallgatók tanulásának és a tőlük származó visszajelzések mélyebb elemzésével; (2) a másik az új választható oktatási, fejlesztési feladatok, valamint az ehhez kötődő kísérletezés. Ezek a tanulási utak már sokkal nagyobb lehetőséget nyújtanak az oktatói ágencia megjelenésére. A saját szakmai tanulás, fejlődés alakítására egyértelmúen nagyobb hatással vannak maguk a kezdő oktatók, ugyanakkor ezzel együtt jár a korábbi szervezett támogatás szinte teljes eltúnése.

A hallgatóközpontú tanítási gyakorlat kialakítása során alapvetően építenek a saját tanításuk elemzésére, a hallgatóik aktivitásának, elégedettségének, visszajelzéseinek elemzésére. "Tehát amit addig is tudtam, hogy a hiteket, a nézeteket nem lehet [a tanításból] kizárni, azt ott nagyon erősen megtapasztaltam, és ott átfordult az a fejemben, hogy igazából az én hatásomnak minek kéne lennie.” (PA). „megéri, mert látom a[z extra konzultáció] hatását, hogy a gyakorlaton, meg a konzultáción is sokkal aktivabbak, meg segít nekik a vizsgán, úgyhogy egyelöre még próbálok rá időt szakítani" (OA). Jellemző, hogy az új gyakorlatokkal bátrabban kísérleteznek új tantervi vagy plusz kurzusok esetében (JA, OA), új oktatási-fejlesztési feladatok esetében, pl. hallgatói mentorprogram kialakításakor (JA), tananyagfejlesztés kapcsán (KA). Ezeknél az új oktatási, fejlesztési feladatoknál viszont egyálta lán nem jelenik meg az a fokozatos bevonódás, támogatás, mint a lelkes kezdő időszak oktatóvá válásában.

\section{A tapasztalt oktatók}

Ahogyan a tapasztalt oktatók utólag úgy értelmezték, hogy kezdőként leginkább a nem tudatosan átgondolt oktatás jellemezte őket, úgy a tanulásuknál is gyakran megjelenik a tanulás esetlegessége, nem tervezett, átgondolatlan volta: „az oktatásnak valamiféle érési folyamata az biztos, hogy zajlott, csak ez nem egy nagyon tudato san irányított, megélt történet volt” (KB). „Eligazítás nem volt, hogy hogy is kéne, mit is kéne [...] amit az ember elles, vagy amit az egyetemen másutt tanul [...] aztán vagy múködik, vagy nem" (OB). Jellemző a saját tapasztalatok gyújtése, a próba-szerencse tanulás, a kollégákkal való beszélgetés, óravázlat készítés, majd kipróbálás, a kezdő oktató felé közvetített magas elvárások észlelése, más oktatókkal való együttmúködés, az oktatói minták követése: „jó pár dolog, amit tanítok, azt nyilván diákként is megéltem, tehát hogy nekem tanították” (KB), vagy akár pedagógiai képzésen való részvétel is. Ugyanúgy megjelenik a négy szakterület közül háromnál a kezdő oktatókat támogató formalizált struktúra, fokozatos bevonódás is: a tapasztalt oktatók értelmezéseikben mégis e tanulási formák mozaikosságát, nem tudatosan szervezett voltát emelik ki.

A tudatos oktatóvá váláshoz kötődően a tanulási folyamatban erős: a) az átgondolt, célorientált vagy problémamegoldó kísérletezés elsősorban egyéni szinten; valamint b) a külföldi példákból, együttmúködésekből, konferenciákból vagy az egyetemen kívüli szakmai gyakorlatból történő tanulás. Bár a kezdő oktatók is szívesen kísérletezgettek a hallgatóközpontú tanítás kapcsán, a tapasztalt oktatók esetében nagy szerepe van a tu- 
datosságnak, annak, hogy a kísérletezés határozott pedagógiai célok, koncepció mentén formálódik: „az, hogy én hogyan értékelem a hallgatókat, meg mit csinálok, abban azért az elmúlt időszakban voltak kísérletezések, meg voltak mindenféle változtatások, amik mögött valahol ez a filozófia [fejlesztő értékelés]" (KB). Vagy éppen problémák felismeréséből táplálkozik a pedagógiai megoldásokat kereső kísérletezés: „ez a felület, hogy meg lehet találni az oktatót akármikor, aztán majd válaszol, ez egy kicsit nehézkes talán. [...] mindenesetre végső soron ezek a változások vezettek oda, hogy elkezdtem kipróbálni ilyen-olyan megoldásokat: kis online tesztet, ami egyből kirajzolja, ki mit válaszolt névtelenül, [...] feedbacket érdemes adni. Tehát azt mondanám, hogy talán professzionálisabban állok hozzá a dolgokhoz" (OB).

A saját intézményen túli tanulási tapasztalatok, vagy a fejlesztésekben, gyakorlatokban való részvétel kifejezetten erősen és közvetlenül hat az oktatók pedagógiai megközelítésére, az oktatói önértelmezésben lényegessé váló tudatosságra, szemléletmódra: „alapvetően megváltoztatta azt, ahogyan a felsőoktatásról gondolkodom. Tehát olyan szintú tudatosságot láttam ott [a fejlesztésben együttmüködő külföldi partnernél]. Hogy mondjak egy példát, ami szerintem nekem a legerősebb olyan példa volt, ami befolyásolta a gondolkodásomat ebben, ahogy átépitették az épületet [...] a közösségi épületfejlesztés" (PB). Az egyetemen kívüli szakmai munka meghatározó tanulási tapasztalatát mutatja a következő idézet: „azt a szakmát, amit aztán elméleti szintre emelve lehet tanítani, azt én ott [az adott szakmában] tanultam meg [...] én azért dolgozom ott, hogy jobban tudjak tanítani” (JB). A jellegzetesen saját intézménybe zárt tanulási tapasztalatok mellett kulcstényezővé válik az intézményen túli oktatási, fejlesztési, gyakorlati részvétel és az ezáltal történő tanulás. „A steril egyetembeli élet”-ből (JB) való kilépés meghatározóvá válik a tudatos és markáns oktatói elképzelésekre épülő oktatói identitás alakulásában.

Az oktatás komplexitásában hívő oktató képe általában akkor jelenik meg, ha már az oktatói feladatok kellően differenciáltak, nemcsak tantermi környezethez kötődnek; továbbá számos, a kurzusok tartásán túli feladat és szerep is megjelenik. Emiatt a tanulási tapasztalatok az új feladatokhoz, fejlesztésekhez kötődnek, s erős bennük az oktatói ágencia, ebben az időszakban az oktatók már inkább kezdeményezőnek, az oktatótársak támogatóinak látják magukat. Jellemzően az általuk kezdeményezett vagy rájuk rótt munkában is előtérbe állítják a kollektív oktatásfejlesztést, az együttmúködést a kollégákkal. „Állandóan tematikákban kellett gondolkodni. Tehát abban, hogy akkor most mit is tanítsunk, és hogyan csináljuk. [...] és ezek mindig komoly változtatást je lentettek. [...] nagyon intenzív és tudatos fejlesztés volt, hogy egyre több esetjogot tanítunk" (JB). A tanulás erős mozgatórugója a felelősség megtapasztalása is: „ezek a kvázi vezetői feladatok nagyon sok tapasztalati lehetőséget adtak az életemben. [...] Komolyabban vettem, mert úgy éreztem, hogy más emberek ottani tevékenységéért is én vagyok a felelös, s akkor jobban kell azt értenem, hogy mi történik" (PB).

\section{Tapasztalt oktatók vezetői gyakorlattal}

A kezdő oktatói időszak tanulását leginkább a saját tapasztalatokból való tanulás jellemzi, ami így sikerekhez és kudarcokhoz egyaránt vezetett. „Az oktatásban az első nyolc évét, azt kidobhatja [az oktató], de nem jön el a második 8 év az első 8 év nélkül. [...] Tehát én az összes létező hibát elkövettem az első nyolc évben, amit el lehet követ ni” (JC). Bár beszámolnak a hagyományos, fokozatos oktatói bevonódás támogatásáról, a támogató szakmai közösségről, meghatározó a magukra utaltság élménye a tanulás kapcsán. A kezdő időszakot „mélyvízbe dobás”ként (JC), magára hagyottságként élték meg: „[az ember] magára marad, és magának kell átlátnia egy tananyagmennyiséget, vagy elvárásokat megfogalmazni, hogy azt hogyan lehet strukturálni, hogyan lehet fölépíteni, abból hogyan lehet értékelési rendszert összeállitani” (PC). Tanulásukhoz kevés konkrét segítséget kaptak, de ahogyan az 
egyik oktató visszaemlékszik, nem is kértek - nem jellemző ebben az időszakban, hogy az oktatók kezdeményezőek, nagyfokú ágenciával rendelkeznének a szakmai tanulásuk kapcsán.

A tanulásközpontú oktatói önértelmezésben a tanulásközpontú tanítás, a kísérletezés/fejlesztés, valamint a szakmai fejlődés, tanulás egymásba fonódik. A tanulás folyamatára a rendszeresség, folyamatosság jellemző: „én lépten-nyomon tapogatózom abban, hogy hogyan lehetne ezt abban az értelemben jobban csinálni, hogy ne ez a passzív befogadás legyen a hallgatók részéröl” (OC). „Ez egy szerves folyamat, tehát hogy én bizonyos értelemben minden héten változtatok rajta, tehát bizonyos értelemben én minden héten szembesülök azzal, hogy, hogy ez hallgató már más, mint a múlt heti hallgatóm, meg a tavalyi, meg tavalyelötti, és pláne más, mint a tíz évvel ezelötti, vagy a húsz évvel ezelótti hallgató" (JC). Már ebben az időszakban nagyon jelentős a szakmai közösségek szerepe a tanulásban, akár több közösségé, s legyen akár külső, akár a felsőoktatáson belüli e közösség. A közös munka, a közös fejlesztések, kísérletezések mind a kölcsönös, együttműködésen alapuló szakmai tanulásra épülnek. „Nincsenek saját tulajdonok, itt mindenki a közösbe rakja bele az anyagát” (JC).

A harmadik időszakban jellemzően a tanulási folyamatok kezdeményezőivé válnak az oktatók. Együttmúködéseket szerveznek, szakmai közösségeket erősítenek meg, személyes támogatást nyújtanak, olyan fejlesztési feladatokat kínálnak, amiben szükséges az együttműködés: „utóbbi időben a kezdeményezéseink részeként lett olyan, hogy több tanszék csinál egy tárgyat projekt jelleggel” (KC). Emellett tipikus tanulási út az oktatáshoz, képzéshez kötődő vezetői szerep kapcsán az átmeneti tanuló időszak. Ez azt jelenti, hogy egy évig a korábbi felelőssel együtt dolgoznak a feladatokon, és ebben a kvázi mester-tanuló viszonyban tanulják az új szerepet.

\section{Az oktatók identitásával, szakmai fejlődésével és tanulásával kapcsolatos eredmények összegzése}

A kutatás arra vállalkozott, hogy az oktatói alidentitás változásait, alakulását ragadja meg narratív megközelítéssel, ezáltal az identitások folytonos alakulását, változási tendenciáit azonosítsa, hozzájárulva ezzel az eddig inkább az oktatói identitások tipizálására fókuszáló kutatások árnyalásához. Az eredményeket a kutatási kérdések két fő fókusza szerint összegezzük: 1) az oktatói alidentitás változásai mentén és 2) az oktatói identitásokhoz, szakmai fejlődéshez kötődő tanulás sajátosságai kapcsán.

Az oktatókkal készített interjúk alapján jól kirajzolódnak az oktatói alidentitás változásai, az önértelmezés jellegzetes mintázatai, s azonosíthatók radikális és inkább kisebb léptékű változások is (Id. 1. ábra). Mindhárom oktatói csoport az első időszak fő sajátosságának a kezdő oktatóképet tartotta. Akik még a jelenben is inkább a pályájuk elején tartanak, ehhez az időszakhoz kötődően több pozitív érzelmet hívtak elő, míg a most már több tapasztalattal rendelkező oktatók visszatekintve azt emelték ki, amit ma meghatározónak tartanak oktatói identitásukban, de akkor még nem volt rájuk jellemző: egyfelól az oktatói tudatosságot, másfelól a sokféle és sok esetben újító tanítási tapasztalatokat.

A kezdő oktatói időszak után bár vannak hasonlóságok az egyes oktatói csoportok önértelmezései közt például, hogy valamilyen formában a hallgató- és tanulásközpontú gyakorlatok megerősödnek, s hogy egyre több oktatáshoz, oktatásfejlesztéshez kötődő feladat és szerep felvállalására is sor kerül -, inkább az oktatói önértelmezések, a szakmai fejlődés eltérő jellegzetességei válnak meghatározóvá. A pályájuk elején járó oktatók radikális változásnak látják szakmai önértelmezésükben, fejlődésükben azt, amikor gyakorlatukban a hallgatóközpontú megoldások erősödnek fel. Ebben a váltásban különösen meghatározó, hogy inkább a tanítási gyakorlathoz, mint a tanítási megközelítésekhez, elképzelésekhez kötődik a változás. Emiatt viszont kevésbé 
koherensen alakítja át az oktatók tervezéssel, tanulásszervezéssel és értékeléssel kapcsolatos gyakorlatát, bár jellemzően a hallgatóközpontú gyakorlat több elemet is érint ezekből. Ráadásul ez a radikális változás időben gyakran összekapcsolódik azzal is, hogy az oktatók már magabiztosnak érzékelik magukat. A korábbi kutatási eredményekhez (vö. Åkerlind, 2003; 2011; Trautwein, 2018) képest mindez új szempontokat is felvet az oktatói önértelmezés alakulása kapcsán. Egyrészt a magabiztos és a hallgatóközpontú tanításra figyelő oktató képe nem feltétlenül egymásra épülő fejlődési szakaszok, lépések, hanem akár egymással párhuzamosan is alakíthatják az oktatói önértelmezés alakulását. Másrészt felveti annak lehetőségét, hogy a kezdő oktatók a pályájuk elejétől fogékonyak a hallgatóközpontú tanítás megoldásaira, de a hallgatóközpontú tanítás gyakorlatának egyes elemei előbb épülhetnek be az oktatók munkájába, mint az ehhez kötődő hallgató- és tanulásközpontú elképzelésrendszer.

A tapasztalt oktatók mindkét csoportjánál viszont éppen nem a gyakorlati megoldások, hanem a „mögöttes” tudatos pedagógiai megközelítések, a tanulásközpontú pedagógia az, ami jelentős fordulópont a kezdő oktatói időszakhoz képest. A tapasztalt oktatók csoportjában jól azonosítható volt a pedagógiai szakkifejezésekkel vagy kevésbé szakmai nyelven, de pontosan körülírva használt pedagógiai elképzelések felvállalása: az élményközpontú pedagógiától a személyre szabott értékelésig. A vezetői szerepben is lévő csoportnál kevésbé kontúros pedagógiai elképzelések kerültek elő, inkább átfogóan a tanulásközpontú szemlélet, viszont itt már nemcsak a hallgatókra vonatkozóan, hanem a saját oktatói tanulásuk szempontjából is kiemelődik a tanulás folyamata, folyamatossága - ami jelentősen alakítja az oktatói önértelmezésüket. Mindkét tapasztalt oktatói csoportnál jelentős az egyéni oktatói szerepértelmezésen való túllépés, az oktatói identitásértelmezésben a kollektív megközelítések megjelenése (akár képzésekhez, akár oktatói közösségekhez kötődően). Az oktatói önértelmezésekben meghatározó módon tehát csak a későbbi időszakoknál jelenik meg az oktatói közösségek szerepe, pedig van Lankveldék kutatása alapján (2017) az oktatói összetartozás érzése az egyik lényeges, az oktatói identitásalakulásra pozitív hatással bíró elem. Az oktatói közösségek támogató szerepe természetesen lényeges a kezdő oktatóknál is, de nem az oktatói önértelmezésük számára meghatározó módon: a közös tanítási célok, megközelítések, közös fejlesztések, a tanulás kölcsönössége akkor még nem válik meghatározó erővé.

Az oktatói önértelmezések, szakmai fejlődés szempontjából lényeges formáló erők a különböző speciális oktatási vagy oktatásfejlesztői szerepkörök megjelenése. Az élettörténetek lényeges tanulsága, hogy akár már a kezdő időszakban is felvállalhatnak ilyen feladatokat, szerepeket az oktatók, például tananyagfejlesztő, mentorprogramot kialakító. Úgy túnik, hogy e speciális szerepek kapcsán nincs átgondolt szakmai fejlődési út: egyéni szinten csak a fejlesztésekre való nyitottságra van szükség, intézményi szinten pedig nem merül fel az oktatásfejlesztővé válás folyamatának támogatása, vagy akár az első időszakban a felkészítés - legalább a szocializáció szintjén úgy, mint a tanítás kapcsán. Bár Remmik és munkatársai (2013) foglalkoznak a sokféle szereppel rendelkező kezdő oktató típusával, de kutatásukban ezek az oktatók jellemzően a felsőoktatáson kívül vállalnak szerepet, jelen esetben pedig épp az látszik, hogy az egyetemen belül is számos, nem a szűken vett tanításhoz kötődő szerepet vállalnak magukra, ami éppen erősíti az oktatói identitásukat. A tapasztalt oktatók is erőteljesen kiveszik részüket az oktatásfejlesztésből, fontos önértelmezési elem az oktatásfejlesztői, újító szerep, ami egyáltalán nemcsak formálisan elismert pozíciókhoz kötődik. Az oktatásfejlesztői szerepek jellemzően jól illeszkednek az oktatói önértelmezésekbe, egyfajta lépcsőzetes szakmai fejlődés érzékelhető: az egyéni kísérletezésektől a közös fejlesztések felé, az oktatói modellé válástól a más oktatók támogatásáig. Csupán a vezetői gyakorlattal rendelkező tapasztalt oktatók egyik csoportjánál érzékelhető a koordinátor szerepkörrel megjelenő radikális váltás, s az ezt kísérő feszültség: az oktatói, valamint a koordinátor, oktatásfejlesztő és - 
szervező alidentitás közt. Nevgi és Löfström (2015) kutatásában elkülönült csoportként elemezte azokat az oktatókat, akik inkább oktatónak/kutatónak vagy éppen oktatásfejlesztőnek látták magukat, s ez utóbbi csoportra a tanítás kevésbé elmélyült reflexiója, valamint az egyéni fókusz helyett inkább a közösségi szintű szakmai fejlődés volt jellemző. Ugyanakkor jelen kutatás éppen azt jelzi, hogy az oktatásfejlesztéssel kapcsolatos vezetői szerepekhez különböző önértelmezések kapcsolódhatnak: felerősödhet egyfelől az oktatói modell és újítások terjesztője önértelmezés, másfelől az oktatásfejlesztést, - szervezést és tudásmegosztást előtérbe állító koordinátor felfogás is. A szakmai fejlődés szempontjából meghatározó útnak látszik, hogy akik inkább az oktatói modellként, az újítások terjesztőiként gondolkodnak magukról, azoknál korábbi gyakorlatukban, tanulásukban meghatározó volt a kísérletezés, fejlesztés, újítás.

Az oktatói identitásalakulás és szakmai fejlődés az élettörténetekben egyáltalán nem kapcsolódik az oktatói karrier hagyományos lépcsőfokaihoz, egyetemi beosztásokhoz. Az oktatói identitáskontruálásban találtunk eltéréseket a kezdő, tapasztalt, valamint a tapasztalt vezető oktatók csoportjai közt, de a szakterületek szerint jelentős különbségek nem voltak kimutathatók a mintánkban.

Az oktatói identitás és szakmai fejlódés szempontjából is kulcskérdés, hogy az oktatók élettörténetükben hogyan vélekednek a tanulásról-tanításról, valamint hogy oktatóként ők milyen módon tanulnak. A kezdő oktaók a tanulás-tanítás kapcsán leginkább a hallgatóközpontúság felé mozdultak el, ami azt jelenti, hogy a hallgatók igényeire akarnak figyelni, s az ennek megfelelő tanulásszervezési módokat igyekeznek beépíteni a gyakorlatukba. Gondolkodásukban megjelenik az a hallgatói igény, hogy ne unatkozzon a hallgató, de az is, hogy értelmezik, mire lesz szüksége végzettként a hallgatónak (pl. önálló véleményalkotás). $A$ tapasztalt oktatóknál látszik, hogy a tanításról-tanulásról való tudatos gondolkodást, elköteleződéseket tartják fontosnak. Ennél az oktatói csoportnál felértékelődik, hogy legyen megfelelő pedagógiai, szakmai háttér a tanulás-tanítás értelmezéséhez, náluk már nem annyira csak a hallgatói igények jelennek meg, hanem a tanulás folyamat jellege (pl. kurzusokon átívelve, képzés szintjén). A megalapozott pedagógiai tudás felértékelődik, saját szakmai fejlődésük, tanulásuk kapcsán is az egyik legfőbb cél és út éppen ennek erősítése. Végül a tapasztalt oktatók vezetői gyakorlattal azok, akik azon túl, hogy tanulásközpontúan, a tanulás folyamatára és támogatására fókuszálva gondolkodnak a tanításról, önmagukat is tanuló oktatóként értelmezik. A szakmai fejlődés egyes időszakaiban a tanulásközpontúság elemeiből más és más erősödik meg, ami által egyre differenciáltabbá válik e koncepció - ami lényeges támpontot nyújthat az oktatók szakmai fejlődését támogató fejlesztéseknek.

Az oktatók tanulásának módjaiban és tanulásuk támogatásában vannak az elejétől fogva hangsúlyos közös elemek, például ilyen a különböző mértékú kísérletezés, újítás és a tapasztalati tanulás. Vagy az, ahogyan a pá lyára kerülnek: három kivétellel mindenki ott kezd el tanítani, ahol tanult is; s már hallgatóként bevonódnak az oktatásba, fóként azok, akik a tapasztalt oktatók csoportjaiba tartoznak, összesen heten a 12 oktatóból. Ugyanakkor a szakmai fejlődés egyes időszakai, valamint a szak- és tudományterület szerint is lehetnek eltérő sajátosságok.

A kezdő oktatók tanulása és támogatása kapcsán jellemző a szakmai tanulás fokozatosságának biztosítása, alapvetően ez a tanulási folyamat a legitim periférikus részvétel szerint szerveződik (vö. Wenger, 1998), a kezdő oktató először a könnyebb, kisebb feladatokban, gyakorlatokban vesz részt, s fokozatosan vezetődik be az egyre komplexebb, az adott oktatói közösség számára egyre lényegesebb feladatok elvégzésébe. Ez a támogató struktúra, a fokozatos bevezetés módja erőteljesen kapcsolódik a szak- és tudományterületi sajátosságokhoz (pl. mi számít központi és periférikus oktatási tevékenységnek). Minden szakterületen él egyfajta tradicionálisan kialakult támogató rendszer, kivéve a pedagógusképzés területén. Az utóbbi területen megjelenő el- 
lentmondások, feszültségek további vizsgálatra érdemesek: a tanulás-tanítás világához a szakmai tartalom mentén éppen a legközelebb álló terület nem foglalkozik a kezdő oktatók tanulását támogató rendszerrel, a kezdő oktatók tudatosan tervezett szakmai támogatásával. Összességében - főként a tapasztalt oktatók viszszaemlékezései alapján - azt láthatjuk, hogy e támogató struktúra ellenére a kezdő oktatói tanulást inkább mozaikszerűen élik meg, kevésbé látják magukat szakmai fejlődésük ágens irányítójaként, $s$ a támogatás személyre szabott, konkrét segítséget jelentő formái is inkább hiányoznak. A hallgatóközpontú tanítási gyakorlat felerősödéséhez a kezdő oktatók esetében nem a támogató struktúrák, hanem inkább a hallgatók visszajelzései váltak meghatározó tanulási forrásokká, ami egybecseng a hallgatói visszajelzések fontosságának eredményeivel (van Lankveld et al., 2017), valamint a kezdeti tanulási időszakban a hallgatói visszajelzések, hallgatókkal való konfliktusok szakmai fejlődést, tanulást ösztönző voltával (Trautwein, 2018).

A tapasztalt oktatók csoportjai esetében a kezdő időszak után jellemzően felerősödik a kísérletezések, újítások során a pedagógiai tudás iránti igény, ekkor jelenhet meg a szakmai anyagok olvasása, konferenciákon való részvétel, s legfőképpen olyan szakmai együttműködések, amelyekben az oktatók szakmailag sokat tanulnak, fejlődnek, amelyekre a kölcsönös tanulás jellemző. Fontos, hogy ezek a szakmai együttmúködések és az ehhez kötődő kölcsönös tanulás intézményen belül, de jellemzően intézményen kívül, túl is meghatározó. A szakmai fejlődés szempontjából ekkor válik igazán meghatározóvá a közös tanulás, s az ehhez kötődő kollektiv ágencia megélése. Jellemző a közös célokon, irányokon való gondolkodás, közös oktatásfejlesztési döntések meghozatala - amiben már a tapasztalt oktatói csoport is jellemzően kezdeményezően és felelősségteljesen vesz részt. A tapasztalt oktatók vezetői gyakorlattal pedig már tudatosabban, tervezettebben gondolkodnak a kollégák tanulásának támogatási módján is. Ezen túl a vezetői gyakorlattal rendelkező tapasztalt oktatók esetében jelent meg még egy jellegzetes tanulási mód, ami egyértelműen az oktatástervező, -fejlesztő, -szervező szerepekhez kötődik, mégpedig a tanonckodás modellje (vö. Collins, 2006): az adott képzésfelelősi, tanulmányi felelősi szerepkör átvételekor kb. egy tanéven át a régi és az új felelős együtt dolgozik. A szakmai fejlődés és tanulás ezen területével kapcsolatban további kutatásokra lenne szükség, fóként azt lenne fontos látni, hogy mik azok a tanulást támogató elemek, amelyek az adott szakmai önértelmezés alakulását komplexen képesek támogatni.

Kvalitatív kutatásunkkal arra vállalkoztunk, hogy egy kisebb hazai mintán az oktatók oktatói önértelmezése it és ezek alakulását, fejlődését, valamint az ehhez kapcsolódó tanulási utakat azonosítsuk. Célunk volt, hogy azonosítsunk az oktatók szakmai fejlődése és támogatása kapcsán releváns sajátosságokat és további vizsgálatokat is igénylő kérdéseket. Az eredmények alapján az oktatói identitás újrakonstruálásában lényegi szerepet töltöttek be: a hallgatóközpontú gyakorlatok, a tudatosan választott pedagógiai megközelítések, az oktatás rendszerszintű értelmezése, a fejlesztői feladatok és szerepek; ugyanakkor további kutatások szükségesek a szakmai fejlődés egyes időszakainak megbízhatóbb jellemzéséhez. Az oktatói önértelmezések és a hozzájuk kapcsolódó tanulási utak összefüggései esetében pedig az eredményeink arra hívják fel a figyelmet, hogy a ta nulást támogató struktúrák gyakran nem a lényegi oktatói identitásalakulási folyamatokat, szakmai fejlődést érintik, hanem inkább csak felszínesen, a mindennapi gyakorlatok szintjét. Mindez pedig az oktatók támogatásával kapcsolatos fejlesztési irányok újragondolását is elősegítheti.

\section{Köszönetnyilvánítás}

A kutatás a Bolyai János Kutatási Ösztöndij támogatásával készült. 


\section{Irodalom}

1. Adriansen, H. K. (2012). Timeline interviews: A tool for conducting life history research. Qualitative Studies, 3(1): 40-55.

2. Åkerlind, G. S. (2003). Growing and developing as a university teacher variation in meaning. Studies in Higher Education, 28(4): 375-90. doi: 10.1080/00122242.

3. Åkerlind, G. S. (2011). Separating the 'teaching' from the 'academic': possible unintended consequences. Teaching in Higher Education, 16(2): 183-195.

4. Akkerman, S. F. \& Meijer, P. C. (2011): A dialogical approach to conceptualizing teacher identity, Teaching and Teacher Education, 27. 308-319.

5. Becher, T. (1994). The significance of Disciplinary Differences. Studies in Higher Education, 19(2): 151-161.

6. Beijaard, D., Meijer, P. C. \& Verloop, N. (2004). Reconsidering research on teachers' professional identity. Teaching and Teacher Education, 20(2): 107-128.

7. Clandinin, D. J. (2007). Handbook of Narrative Inquiry, Sage Publication - Thousand Oaks.

8. Collins, A. (2006). Cognitive apprenticeship. In: Sawyer, R. K. (ed.): The Cambridge Handbook of the Learning Sciences. Cambridge: Cambridge University Press, 47-60.

9. Cordingley, P. (2015). Why is evidence about teachers' professional learning and continuing professional development observed more in the breach than reality? Why has it not stuck? In: McLaughlin, C., Cordingley, P., McLellan, R. \& Baumfield, V. (eds.). Making difference. Cambridge: Cambridge University Press, 53-76.

10. Csíkos, Cs. (2009). Mintavétel a kvantitativ pedagógiai kutatásban. Kutatás-módszertani Kiskönyvtár, Budapest: Gondolat Kiadó.

11. Day, C. (1999). Developing Teachers: The Challenges of Lifelong Learning. Educational Change and Development Series. London: Falmer Press.

12. EC (2014). European Commission Report to the European Commission on New modes of learning and teaching in higher education. High Level Group on the Modernisation of Higher Education.

13. Eteläpelto, A., Vähäsantanen, K., Hökkä, P., \& Paloniemi, S. (2013). What is agency? Conceptualizing professional agency at work. Educational Research Review, (10): 45-65.

14. Hénard, F. \& Roseveare, D. (2012). Fostering Quality Teaching in Higher Education: Policies and Practices. OECD IMHE. Retrieved from:http://www.oecd.org/edu/imhe/QT\%20policies\%20and \%20practices.pdf (2018. 01.30.)

15. Horváth, L., Simon, T. \& Kovács, A. (2016). Development and Embedding of the Horizontal Learning System into the Hungarian Institutional System of Pedagogical Services, In: Livingston, K. - Macfarlane, G. (eds.). Teacher Education Through Partnerships and Collaborative Learning Communities: Conference Proceedings of ATEE 40th Annual Conference 2015. Glasgow: ATEE, 205-216.

16. Kálmán, O. (2016). Az oktatók elképzelései a szakmai fejlődésükről, pedagógiai kompetenciáikról és a tanításukról. In: Garai I., Vincze B. \& Szabó Z. A. (szerk.): Hiteles pedagógia. Tanulmányok Golnhofer Erzsébet tiszteletére. Budapest: ELTE Eötvös Kiadó, 46-58.

17. Kálmán, O. (2018). Az oktatók szakmai fejlődésének és tanulásának megközelítései a felsőoktatásban. In: Fehérvári, A. (szerk.): A Borsszem Jankótól Bolognáig. Neveléstudományi tanulmányok. Budapest: ELTE PPK - L'Harmattan, 218-236.

18. Kelchtermans, G. (2009). Who I am in how I teach is the message: Self-understanding, vulnerability and reflection. Teachers and Teaching: Theory and Practice, 15(2): 257-272. Retrieved from: http://dx.doi.org/10.1080/13540600902875332 (2018. 01. 28.)

19. Kovács, Zs. \& Kereszty, O. (2016): Az oktatási feladatokról és szerepekről való gondolkodás a hazai doktoranduszok körében, Neveléstudomány, 3(4): 5-19. 
20. László, J. (2005), A történetek tudománya. Bevezetés a narrativ pszichológiába. Pszichológiai Horizont, Budapest: Új Mandátum Könyvkiadó.

21. Nevgi, A. \& Löfström, E. (2015). The Development of Academics' Teacher Identity: Enhancing Reflection and Task Perception Through a University Teacher Development Programme. Studies in Educational Evaluation, Evaluating Faculty Development. 46 (September): 53-60. doi:10.1016/j.stueduc.2015.01.003

22. Pataki, F. (2001). Az önéletírás „dramaturgiája”: az élettörténeti forgatókönyvek. In: Uő.: Élettörténet és identitás, Budapest: Osiris Kiadó, 309-359.

23. Patton, M. Q. (2002): Qualitative Research and Evaluation Methods, 3. kiadás, Thousand Oaks, Sage Publications, CA.

24. Polkinghorne, D. E. (1995): Narrative configuration in qualitative analysis. In: Hatch J. A. (ed.): Life History and Narrative. London: Routledge Falmer, 5-23.

25. Rapos, N. (2016). A támogatás értelmezése a személyes szakmai életúton. In: Vámos Á. (szerk.): Tanuló pedagógusok és az iskola szakmai tőkéje. Budapest: ELTE Eötvös Kiadó, 79-102.

26. Remmik, M., Karm, M. \& Lepp, L. (2013). Learning and Developing as a University Teacher: Narratives of Early Career Academics in Estonia. European Educational Research Journal 12(3): 330-341. doi:10.2304/eerj.2013.12.3.330.

27. Riessman, C. K. (2001). Analysis of Personal Narratives. In: Gubrium, J. F. \& Holstein, J. A. (eds.): Handbook of Interviewing. Thousand Oaks, CA: Sage Publication.

28. Sachs, J. (2007): Learning to improve or improving learning: the dilemma of teacher continuing professional development. $20^{\text {th }}$ International Congress for Effectiveness and Improvement.

29. Schluter, J., Seaton, P. \& Chaboyer, W. (2008). Critical incident technique: a user's guide for nurse researchers. Journal of Advanced Nursing, 61(1): 107-144.

30. Shulman, L. S. (2005). Signature Pedagogies in the Professions. Daedalus, 134(3): 52-59.

31. Swennen, A., Jones, K. \& Volman, M. (2010). Teacher Educators, Their Identities, Subldentities and Implications for Professional Development. Professional Development in Education, 36(1-2): 131-148.

32. Taylor, K. L. \& Colet, N. R. (2010). Making the Shift from Faculty Development to Educational Development. In: Saroyan, A. \& Frenay, M. (eds.): Building Teaching Capacities in Higher Education. A Comprehensive International Model. Sterling, VA: Stylus Publishing, 2010, 139-167.

33. Van Lankveld, T., Schoonenboom, J., Volman, M., Croiset, G. \& Beishuizen, J. (2017). Developing a teacher identity in the university context: a systematic review of the literature, Higher Education Research \& Development, 36(2), 325-342, DOI: 10.1080/07294360.2016.1208154.

34. Wenger, E. (1998). Communities of practice. Learning, meaning and identity. Cambridge: Cambridge University Press. 


\section{University teachers' professional development: their identity development and ways of learning}

Even though there has been more attention paid recently to enhancing the quality of teaching and learning in the international context of higher education, the academics' as teachers professional development and learning has been underexplored. The aim of this qualitative research study is to identify the changes in the self-understanding of university teachers and the learning processes involved in identity construction. Life story and qualitative thematic interviews have been conducted with twelve university teachers who are committed to their teaching practice. In our sample four disciplinary fields are represented such as teacher education, law, business, and medicine. From each disciplinary field a novice, an expert, and an expert with a leading educational role were selected. Additional to the life history interview a timeline interview and a critical incident technique were used. In the narrative analysis the identity construction and the specific periods of the development of self-understanding were identified and compared within and between the three university teachers' groups. The findings show that the self-understanding of the three groups of university teachers varies. Among the novice university teachers, a relevant turning point in identity formation is the university teacher with a student-centred teaching practice. Among the expert teachers enhancing teacher awareness and committing to specific pedagogical approaches are the key turning points. The university teachers with leading positions underline the learning-centeredness approach where they see themselves as learners too. The tasks and roles of educational development have an influence on the self-understanding of university teachers and these are important incentives for learning as well. Our study would like to contribute to a more elaborated in terpretation of the learning-centred approach and self-understanding of university teachers, as well as to the sound planning of the supporting system for the university teachers' professional development.

Keywords: university teachers, professional development and learning, narrative research approach 